\title{
Reading between Worlds: Contemporary Greek Women's Writing and Censorship
}

\author{
KAREN VAN DYCK is assis- \\ tant professor in Hellenic Stud- \\ ies at Columbia University. \\ This essay touches on points \\ that are developed in her forth- \\ coming book Cassandra and \\ the Censors: Greek Poetry \\ since 1967 (Cornell UP). She \\ is working on an anthology of \\ contemporary Greek women \\ poets.
}

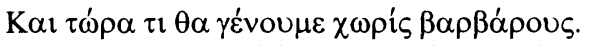

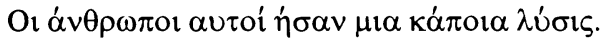

C. P. Cavafy

Now what's going to happen to us without barbarians? Those people were a kind of solution.

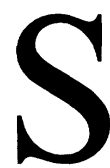

INCE THE PERIOD of the dictatorship (1967-74) women writers have set literary trends in Greece. The most influential poets from the generation that began writing under the dictatorship are women (e.g., Katerina Anghelaki-Rooke, Rea Galanaki, Maria Laina, Jenny Mastoraki, Pavlina Pamboudi), and women wrote many of the best-selling novels published in the late 1970s and throughout the 1980s (e.g., Maro Douka's Fool's Gold [H $\alpha \rho \chi \alpha i \alpha$

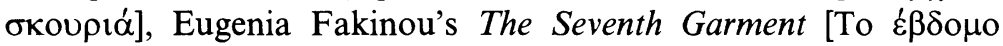

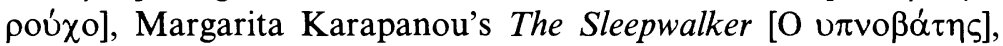

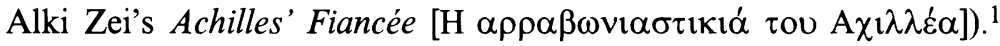
Perhaps because the oral tradition is a mainstay of Greek literature and because women are important as producers in this tradition, female authors have always been an integral part of Greek literary circles. "Good" women writers, however, were assumed to have "risen above" their gender. The category "women's writing" had a derogative or at least restrictive meaning. The critic and novelist Immanuel Roidis made this connotation clear in his discussion of women's writing at the turn of the century: women should write "about needlework and cooking," and when they address public matters, they are mere imitators. To support this claim he quoted the Chinese saying "If the hen begins to crow like a cock, kill her immediately" (85). ${ }^{3}$ Roidis's views, which have been shared by many 
other twentieth-century intellectuals in Greece, may be one reason why some Greek female authors are still reluctant to call themselves "women writers." In the late 1980s and early 1990s critics and poets began to acknowledge the importance of women's writing (Vitti 450; Ma-

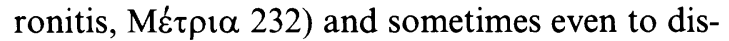
cuss the relation of gender to literature (Frandzi et al.), but none has explored how the rise of women's writing relates to Greek society and politics during and after the dictatorship.

In this article I link the strength of Greek women's writing in recent decades to the authors' willingness to connect censorship under an authoritarian regime and under patriarchy. ${ }^{4} \mathrm{I}$ focus on the ways in which women poets continued to deploy certain writing strategies that, although initiated in response to the dictator's press law, proved useful in articulating domestic power struggles. Drawing on the formative experience of writing under censorship, these writers in the 1980s forged a poetics based on a female relation to language and the literary tradition. I begin by outlining the cultural conditions under the dictatorship - in particular, the colonels' fear of linguistic and sexual undecidability - and show that the figure of woman (such as Lysistrata or Cassandra), used to represent this undecidability, becomes an important site of resistance. I then chart the shift from the allegorical use of the subversive woman in comic strips and novels written in the early 1970s to the linguistic attention women's poetry of the 1980 s gives to mechanisms of censorship. A comparison of Kassandra

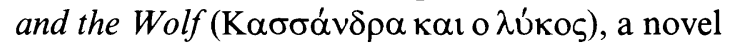
by Margarita Karapanou written under the dic-

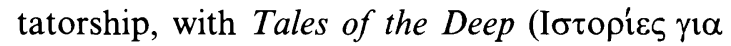
$\tau \alpha \beta \alpha \theta \imath \alpha$ ), a series of poems written after the dictatorship by Jenny Mastoraki, illustrates this shift; while the novel takes as its story line a little girl's undermining of censorship, the poems enact this challenge formally. Tales of the Deep unsettles and disrupts fixed meanings by redeploying the very tactics for stabilizing signification on which censorship relied. Through elliptical syntax and unorthodox punctuation, Mastoraki's language performs the undecidability that woman had come to represent. The displacement of attention from the public enemy to the enemy at home in recent poetry by women has also led to the implication of their own writing in the power dynamics they analyze. Recognizing, as Cavafy observes, that "the barbarians" - whether colonels or men in generalare "a kind of solution," this poetry appears to move beyond substituting one enemy for another and to do so by admitting its discursive complicity in the enemy's operations.

Whereas before the dictatorship censorship and other repressive measures were regarded as externally imposed, after the dictatorship, with the waning of the memory of the civil war (194649) 5 and with the rise of the women's movement, the private and public sphere, outside and inside, "us" and "them," became less and less clearly demarcated. According to many accounts the dictatorship was a time in which the general population was "feminized"; for seven years the subaltern "experiences" of women-claustrophobia, curfews, silencing and censorship, physical restraints-became those of both genders. With the fall of the regime the women's movement gained strength from the public denunciation of these experiences. ${ }^{6}$ It was suddenly possible to make analogies among censorship by an oppressive regime, censorship practiced in the subjection of women, and even the Freudian notion of censorship as a necessary check on the unconscious. ${ }^{7}$ Over the course of the historical period that this article covers, the term censorship therefore accrues new meanings, beginning with the less complicated notion expressed by the dictator's metaphor of Greece as a patient in a cast and moving to the more inclusive definition of recent women's poetry, which connects censorship by authoritarianism, by patriarchy, and by the psyche.

Since the treatment of women's writing as a discrete critical category is still regarded with suspicion by many Greek writers and since I do not wish to efface the specificity of this cultural moment by imposing some transhistorical notion of women's writing on it, I have chosen a more homeopathic approach, which introduces in small doses the feminist issues that cause unease. I therefore compare works by Karapanou and Mastoraki with texts that grapple with similar issues of censorship and authority 
in which the feminist implications are more explicit-specifically, the German writer Christa Wolf's Cassandra: A Novel and Four Essays and the French philosopher Luce Irigaray's Speculum of the Other Woman. I exchange texts crossculturally within the bounds of Europe to call attention to the geopolitical imbalances within the First World. In recent discussions of the relevance of feminist theory developed in the First World to women's writing of other worlds, the West is often constructed as a homogeneous place (Spivak, "International Frame" and "French Feminism Revisited"; Carby; Hooks). Hazel Carby, for example, maintains that "the metropolitan centres of the West define the questions to be asked of other social systems" (216). My intervention in this debate is to highlight the differences among the metropolitan centers of the West, in particular between the powerful culture industries of Berlin or Paris and what Greeks sometimes refer to as the "Secondand-a-Half World" of Athens. ${ }^{8}$ Although I use Wolf's and Irigaray's texts to open a feminist perspective on Greek writing, I do not give them the ultimate authority; I also suggest ways in which the work of Karapanou and Mastoraki uncovers alternative readings of the German and French texts. My aim then is threefold: to trace the rise of women's writing in Greece, to connect this rise to the thematic and formal response to censorship in women's writing over the past two decades, and to use a reciprocal mode of reading between worlds that can tentatively account for this connection.

\section{Greece as a Patient in a Cast}

In Greece most citizens' experience of the colonels' regime was closely tied to issues of language and censorship. Overnight the official language changed, and demotic was no longer the language of education. Unexamined rights like freedom of the press and the unhindered distribution of books could not be taken for granted. The book index banned not only those titles that openly criticized dictatorships but also those whose authors' names sounded vaguely Russian and even ancient texts that parodied the misuse of power, like Aristophanes's Birds. To quell the opposition's use of metaphor, the regime included in the press law the ludicrous mandate that all books bear titles corresponding exactly to their contents. Authority depended on the strict regulation of meaning. Any kind of uncertainty was threatening.

This attitude was also clear in the dictator's rhetoric. In the "Greece for Christian Greeks," as the dictator Yeorgios Papadopoulos called his promised land, words and things would regain their original perfect fit. To this end many of his metaphors and puns attempt to efface their own figurativeness, presenting themselves as the literal truth. In his famous speech at a press conference he describes Greece as a patient in a cast:

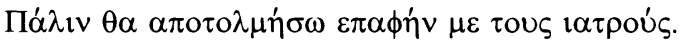

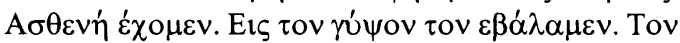

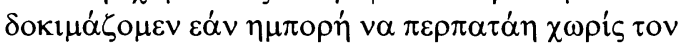

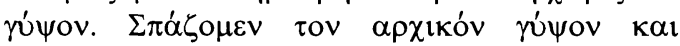

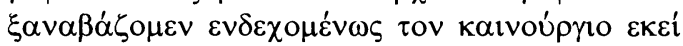

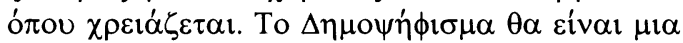

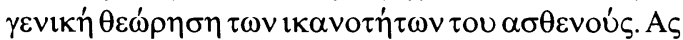

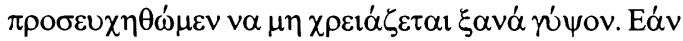

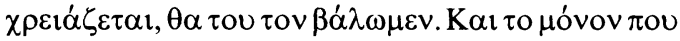

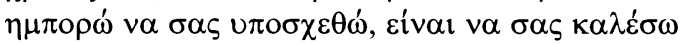

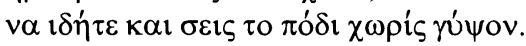

Again I shall venture contact with the doctors. We have a patient. We have put him in a plaster cast. We see if he can walk without the cast. We break open the cast and eventually replace it with another where it is needed. The referendum will be a general examination of the patient's capacities. Let us pray that there will not be further need of a cast. If there is, however, we shall put it back on. And the only thing that I can promise you is an invitation to see for yourself the leg without the cast.

His invitation to journalists to see the leg for themselves treats a metaphor literally. Ultimately his use of metaphor is frighteningly consistent with his distrust of the opposition's use of figurative language. In both cases metaphor is effaced in an appeal to unequivocal meaning.

The regime's erasure of the distinction between the figural and the literal led the resistance writers to a heightened awareness of the difference. Their challenge was to expose the contradictions and hypocrisy that the regime was busy 
concealing. One of the most successful tactics was parody: writers would seem to cooperate with Papadopoulos's desire to make everything fit perfectly but in effect would subvert it. If books had to have titles that corresponded exactly to the contents, then the resistance would use empty titles such as Eighteen Texts, Six Poets, New Texts 1, and New Texts 2. Layout and typography were also effective ways of parodying censorship. Editors of certain newspapers were known for printing the regime's mandatory statements in the same type and format as obituaries.

Not surprisingly, the regime sought to eradicate confusion and mixed messages not only through the press law but also through dress codes, curfews, and moral expectations. The corollary of the censor's demand for a perfect fit between what one said and what one meant was the moralist's demand for a perfect fit between what one looked like and who one was. Any kind of undecidability, textual or sexual, was considered subversive. The newspapers of 1969, when censorship was most severe, are full of references to the androgynous and gender-bending styles of hippies and male homosexuals. As far as the regime was concerned, the disruption of conventional sexual distinctions by men with long hair and by homosexuals was as threatening as the disjuncture between word and meaning that a pun foregrounds. While Colonel Papadopoulos railed against metaphor and hidden meaning, another prominent member of the regime, Colonel Ladas, proclaimed long hair "the hirsute flag of nihilism" (Clogg 42) and closed down the magazine Eıkóves for publishing an article entitled "The Dark World of the Third Sex."

Interestingly, the regime directed its intolerance of undecidability for the most part at the feminizing of things masculine, at the danger that men might become women, not at the opposite process. And it is in this context that the adoption by cartoonists and writers of the figure of woman as the site of their resistance must be placed. Again and again opposition to the regime is thematized through the sexually and textually ambivalent figures of Cassandra, Little Red Riding Hood, Lysistrata, and Scheherazade, the heroine of The Thousand and One

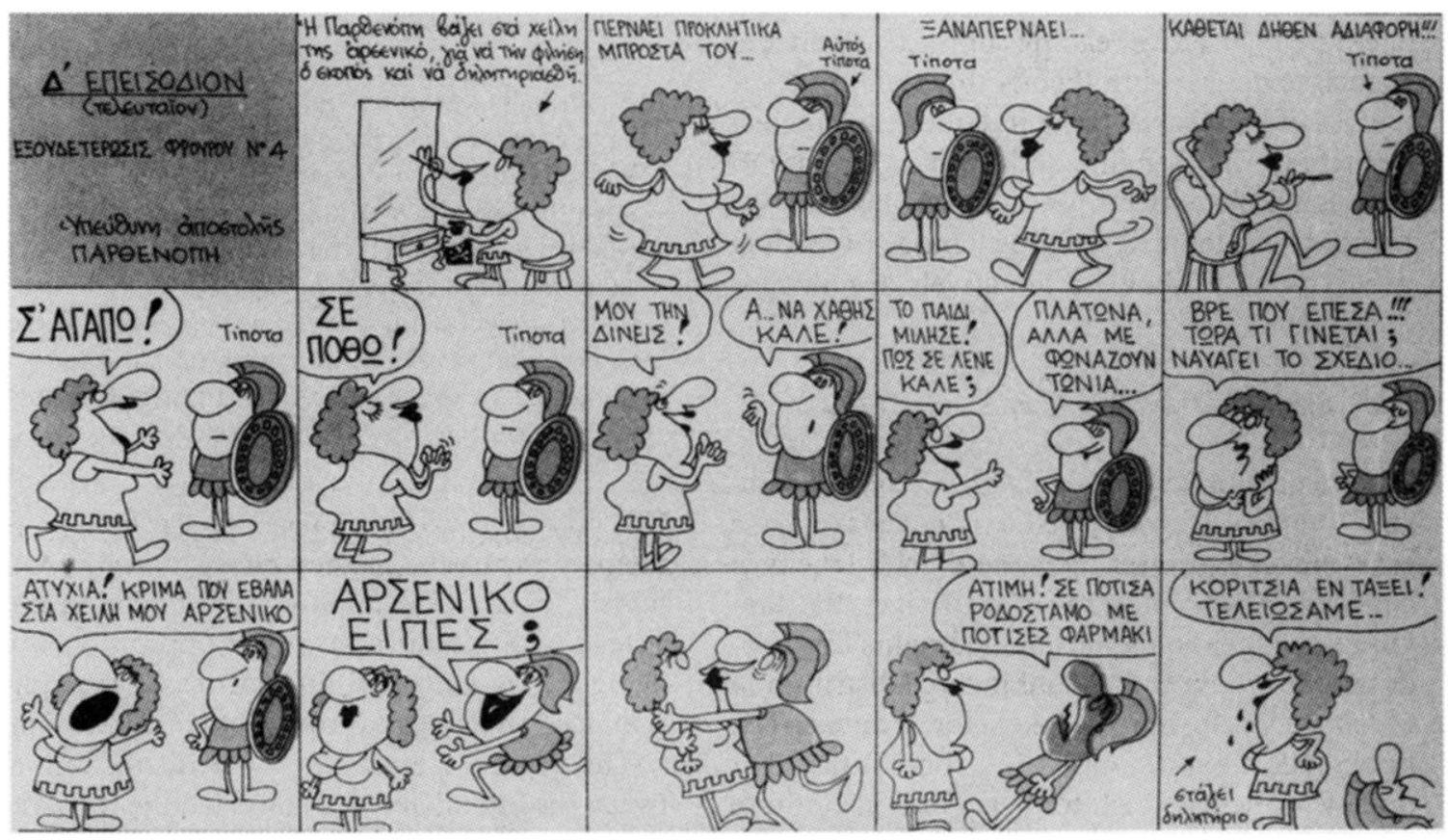

An excerpt from the 1 March 1974 installment of the comic strip "Lysistrata," by Kyr. (Reproduced by permission of the artist.) 
Nights - all of whom turned positions of weakness into places of power. Kyr's comic strip

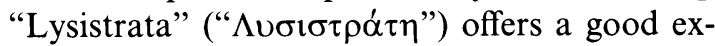
ample. In one episode Parthenope, a cohort of Lysistrata, puts on poisonous lipstick in an attempt to kill a guard by seducing him and thereby to enter the citadel of power, the Acropolis. But the guard turns out to be gay. Parthenope exclaims, Ko'́ $\mu \alpha \pi$ ov $\varepsilon \beta \alpha \lambda \alpha \sigma \tau \alpha \chi \varepsilon^{\prime} i \lambda \eta \mu o v$

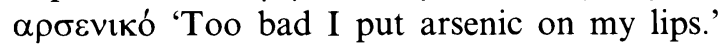
The guard overhears the word $\alpha \rho \sigma \varepsilon v i \kappa o$, which means "male" as well as "arsenic." Taking her for

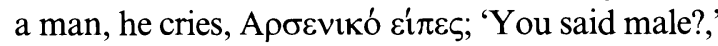
runs up to kiss her, and meets his death. Being seen as something she is not and being understood saying something she does not mean make Parthenope an ideal figure of undecidability.

\section{Kassandra's Wolf and Wolf's Cassandra}

Although in these representations of women as undecidable there is an interesting tension between the struggle against the regime and the struggle for women's rights, the latter inevitably is subordinated to the former; for the most part the resistance uses the figure of woman to underwrite an emancipation that has little to do with women's liberation. Margarita Karapanou's novel Kassandra and the Wolf, however, is a work written under the dictatorship that does not clearly subordinate the feminist project.

The feminist implications of Karapanou's resistance to authority become clear in relation to Christa Wolf's Cassandra. Wolf's volume, containing a novel and four lectures, is much more explicit about the uses and abuses of the figure of woman than is Karapanou's. Written while Wolf traveled through Greece in 1980, the work is an attempt to re-create Cassandra, the ancient prophet, as she was before being written about (287). Wolf outlines how Cassandra became the archetypal woman-as-object, robbed of her autonomy by a culture that began to fear mothers and privilege fathers. The task Wolf sets herself is "to retrace the path out of myth into its (supposed) social and historical coordinates" so that the personal drama of the myth is never the last word (256). Repeatedly she inverts the public and private spheres, showing, for example, how what the male mythologist mourns (i.e., Cassandra's "unfortunate" fate) is not a private affair, the punishment for not reciprocating Apollo's lust, but a public, political one. It was not simply that Apollo rendered her gift of prophecy ineffective by spitting in her mouth but rather that all over Greece the seeress was subordinated to the male priest and slowly forced from the public realm. Cassandra's babble is the symptom not of one woman's madness but of a historical moment that, for many interrelated reasons, inaugurated a new, widespread form of oppression. Wolf's insights about Cassandra are also meant as meditations on the challenges facing contemporary women writers. By fashioning a Cassandra whose subjectivity straddles the public and private spheres, Wolf suggests an alternative position from which East German women might write. ${ }^{10}$

Karapanou's Kassandra and the Wolf can be seen to delineate a similar space for Greek women writers. On one level the novel is a kind of female bildungsroman, thinly veiling its autobiographical content by drawing on the Little Red Riding Hood story: ${ }^{11}$ the small girl, the grandmother, the wolf, and the absent mother of the fairy tale are all transported to a bourgeois household in the center of Athens during and just after a coup. In the light of Wolf's refashioning of Cassandra, Karapanou's Little Red Riding Hood can be read as offering a domestic stage on which the public drama of an authoritarian regime is enacted. Less interested in the origins of myth than Wolf is, Karapanou traces the Little Red Riding Hood story into the "(supposed) social and historical coordinates" of the contemporary moment. ${ }^{12}$ The undecidability proposed by Kassandra's and the Wolf's word games and cross-dressing can be read both as a parody of the regime's rage for order and as a step toward an alternative feminist poetics in which the censoring and censored subjects are not binary oppositions. ${ }^{13}$

Throughout Karapanou's series of short fragments there are the recurrent figures of the General, who is a friend of Kassandra's grandmother, and Peter, Kassandra's butler and babysitter-both of whom, in different ways, have power over the child. Impatient with hier- 
archy, Kassandra sometimes makes fun of them, while at other times she feels sorry for them. In one piece Kassandra, parodying the regime's desire for identity and unequivocal meaning, confesses:

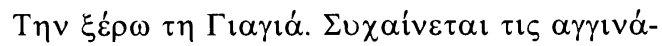

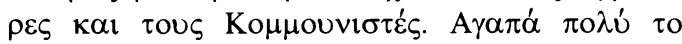

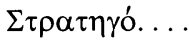

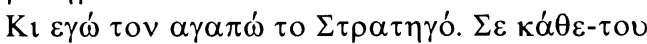

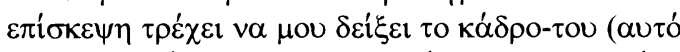

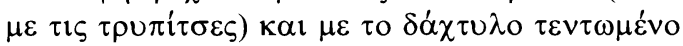

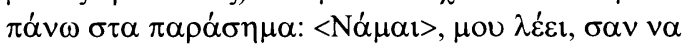

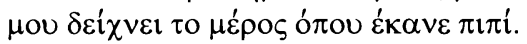

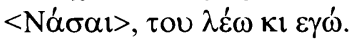

I know Grandmother well. She's crazy about politics. She detests artichokes and Communists. She loves the General very much. . . .

I love the General too. Every time he calls on us, he trots off to where his portrait is hanging (the one with the little holes in it) and, with his finger quivering at the row of medals, says: "There I am," as though he's pointing to the spot where he's done his pipi.

"There you are," I sing back.

While the General gloats over this unmediated reflection of himself and his power - the row of medals - the little girl notices that the portrait is full of tiny holes. By calling attention to the imperfect surface of the canvas, she challenges the whole mimetic project on which his selfsatisfaction relies. According to Kassandra he is neither powerful nor potent but riddled with holes and ridiculous.

But in another passage Kassandra takes a kind of ironic pity on the one in power:

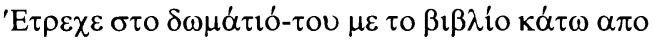

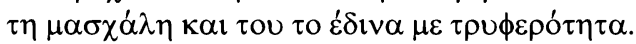

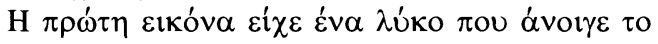

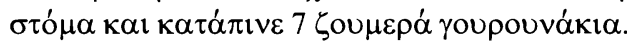

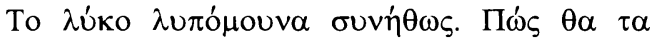

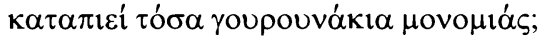

I'd run to his room with the book under my arm and give it to him tenderly.

The first picture was of a wolf opening his mouth to swallow 7 juicy piglets.
It was the wolf I usually felt sorry for. How could he gulp down so many piglets at one go?

Her shifting sympathies disturb the simplicity and neatness of saying what one means and looking like who one is. Politics enter the home, and Kassandra's body becomes an arena of resistance. At every turn her language and behavior undermine the regime's censorship and puritanism. She stutters and stubbornly refuses to do her math correctly; she does not conform to her grandmother's conception of "a good little girl."

Kassandra's stuttering, for example, is a parody of the regime's censorship. The impediment that threatens to eradicate her words instead only defers or displaces them: "Ka-ka-ka-ka-s-ss-sandra" $(134 ; 112)$. The words survive but break apart and form significant puns ( $\kappa \alpha \kappa \alpha$ is a children's term for excrement and more generally for anything bad or naughty). By not letting the censor conclusively delete her words, Kassandra promotes the textual undecidability that is anathema to the regime. Similarly, on her first day of school she annoys her teacher, Miss Ada, by denying that subtraction is possible. Kassandra's point is that nothing can ever be definitively cut out:

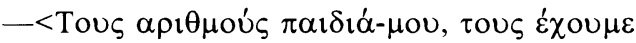
$\gamma \downarrow \alpha \nu \alpha \mu \varepsilon \tau \rho \dot{\alpha} \mu \varepsilon>$.

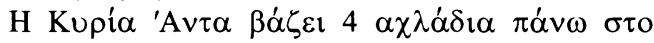
$\tau \rho \alpha \pi \varepsilon \dot{\zeta} \zeta$.

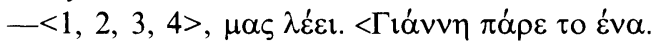

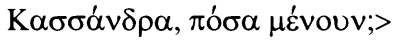

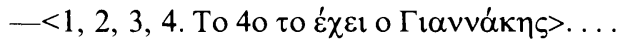

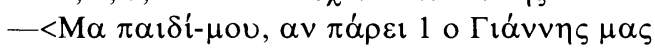
$\mu \varepsilon \dot{v}$ ouv 3>.

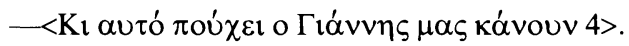

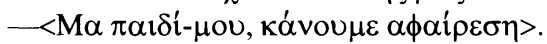

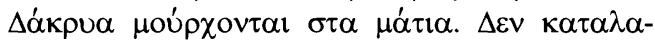
$\beta \alpha i v \omega$.

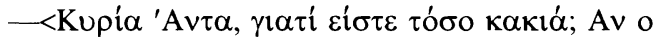

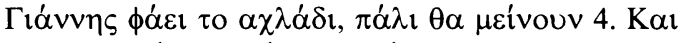

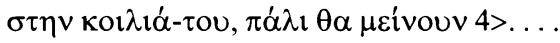

"We have numbers, children, so as to be able to count."

Miss Ada puts 4 pears on the table. 
"1, 2, 3, 4," she says. "Yannis, you take 1. Kassandra, how many do we have left?"

"1, 2, 3, 4. Yannis has the 4th. ..."

"My child, if Yannis takes 1, we have 3 left over."

"And that makes 4, together with the 1 Yannis has."

"My child, we are doing subtraction."

Tears come to my eyes. I don't understand.

"Miss Ada, why are you so bad to me? Even if Yannis eats the pear, we'll still have 4 pears. Together with the 1 in his belly, we'll still have 4 . . ."

In another fragment, "Mother's Present" ("To

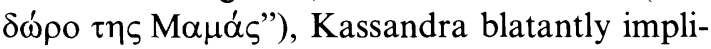
cates herself as the censor. She recounts getting a doll from her absent mother:

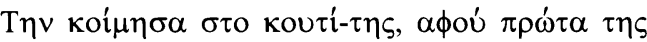

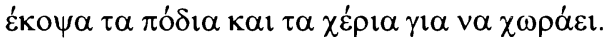

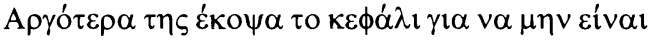

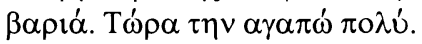

I put her to sleep in her box, but first I cut off her legs and arms so she'd fit.

Later, I cut off her head too, so she wouldn't be so heavy. Now I love her very much.

In a monstrous parody of Freud's fort-da episode, in which a child imitates his mother's departure by throwing a toy out of his crib (Metapsychology 283-87), Kassandra alleviates the pain of separation from her mother by enacting the severing herself. By taking into her hands that which is being done to her, she acknowledges the ways in which redeploying censorship can be empowering. Nonetheless, the heavy irony of the conclusive "Now I love her very much" suggests that simply inverting victor and victim, censor and censored is not a satisfactory solution. As do the displaced syllable or pear, the irony here reminds readers of the violence they may have forgotten.

While reworking the discourse of censorship, Kassandra also reworks assumptions of gender; she parodies the General's need for order by feminizing him, turning him into the maid:

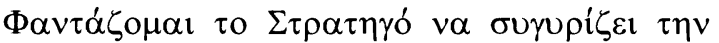

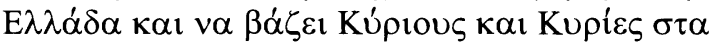

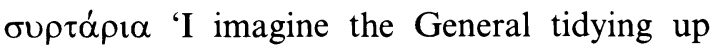
Greece, putting Gentlemen and Ladies in drawers' $(8 ; 5)$. Just as Kassandra's puns and stutters defer linguistic meaning indefinitely, her imaginary cross-dressings postpone gender distinctions. This effect is illustrated by a passage in which the wolflike Peter and Kassandra "play doctor" in a rather unusual fashion. Like many things in the novel, the incident begins as a word game. Peter asks:

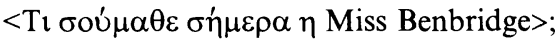

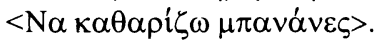

$<\Sigma \alpha v$ Kúplos>;

$<' \mathrm{O} \chi \mathrm{l}, \sigma \alpha v$ Kupía>. . . .

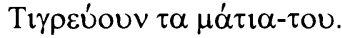

$<\Sigma \alpha v$ Kúplos>;

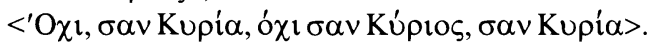

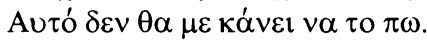

"What did Miss Benbridge teach you today?"

"To peel a banana."

"Like a Gentleman?"

"No, like a Lady." . . .

His eyes go tiger.

"Like a Gentleman?"

"No, like a Lady. Not like a Gentleman, like a Lady."

He'll never make me say it.

A few pages later Kassandra finally finds a way out. She answers, $\Sigma \alpha v$ Kúpros '[L]ike a Gentle-

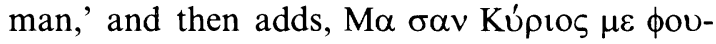

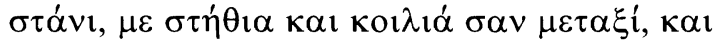

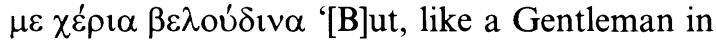
a frock, with breasts and a belly like silk, and velvety hands' $(23 ; 31)$. She both gives in to the wolf and withholds exactly what he wants. By the end of the scene it is impossible to tell who is the victim and who the victor.

It is striking that Karapanou was willing to challenge the strict distinction between victor and victim, censor and censored at a time when the difference was clear. Her move marked a strong departure from Greek literary practice. For generations Greek writers responded mainly in two ways to oppressive regimes: either by taking the "disinterested" position, in which elliptical usage and ambiguity were valid literary 
techniques, or by writing explicitly "engaged" prose or poetry, in which clarity was crucial. But Karapanou, like many young writers of her generation, took an alternative route. Undecidability and multiple subject positions in this novel are not transhistorical, postmodern strategies of evasion but culturally specific modes for challenging the relegation of private and public, personal and political, female and male to separate spheres. The claim of this approach is not simply that it is possible to make a political intervention indirectly but also that the struggles of previously invisible subjects such as women can only be taken into consideration indirectly; expanding the political realm to include areas like sexuality and the body finally permits women's needs to be addressed.

By blurring distinctions this novel allows one form of oppression to act as a metaphor for others. In this way the text bridges the concerns of writers under an authoritarian regime with those of women writers after the regime falls. Kassandra's unwillingness to deliver what is expected of her is a response both to the General and to the only male authority figure at home, Peter. It is also a reminder that one way to challenge a system is to use its tools to different ends, as Kassandra redeploys the censor's tactics so that they destabilize rather than fix meaning; she points out that the pear is still present, even if in Yannis's stomach, and concedes, "[L]ike a Gentleman," but gives the Gentleman a dress, breasts, and so on.

Christa Wolf's writing offers a parallel case for undecidability as political intervention. ${ }^{14} \mathrm{Her}$ Cassandra is also defined by multiple subject positions: "There is something of everyone in me ..." (Cassandra 4). In an interview Wolf recounts that it was through her interest in contradictions and through the fear it provokes in readers that she arrived at the figure of Cassandra. She explains how the effeminate traits of the Kleist character in her earlier book No Place on Earth unnerved readers: "I had deformed him by giving him effeminate characteristics." She goes on to explain readers' unease about "anything hybrid, about fluid transitions, about things not being simply one thing or the other: friend or foe, male or female; a fear of learning to live with rather than against one another" (Fourth Dimension 102). But, like Karapanou, she is careful to emphasize that the breaking of taboos is also an internal process. She says:

Of course, I don't sit down at the typewriter, every time I tackle a new subject, with the intention of offending anybody. No, I want to make myself aware of the things which offend and hurt me.... Before the violent reaction from outside arose, I had to go through my own violent reaction. Like my readers, I am split.

The contradictions that disturb authoritarian rule are the stuff of both Wolf's and Karapanou's work. If the choice these authors made to internalize difference was exceptional in their cultures, it might not be of much interest. But in both cases the choice is a symptom of shifting cultural climates. In Berlin during the 1980s, the members of Frigga Haug's women's collective had a project similar to Wolf's. They traced their stories of growing up onto particular social and historical coordinates. These women's simple yet radical hypothesis was that "in girls, the process of individual socialization is synonymous with the sexualization of the body and its parts" (Hauser 203). And in Greece this collective had an analogue in the journal $\Sigma \kappa o u ́ \pi \alpha$, published from 1979 to 1981 , which raised women's issues less systematically. Wolf's preoccupations, more explicitly feminist than Karapanou's, help relate the Greek author's reworking of the figure of woman simultaneously to the regime and to the growing women's movement. In this light $\mathrm{Ka}$ rapanou's Kassandra offers an alternative solution to the catch-22 of undermining authority, whether the regime's or patriarchy's. Instead of substituting the traditional position of power, the dictator's or the wolf's, with the traditional position of weakness, the woman's, Karapanou constructs a place from which to speak that is always both. ${ }^{15}$

\section{Women's Poetry after the Dictatorship: The Formal Challenge}

As in the comic strips and novels of the 1970s, woman as a symbol of resistance is evident in the 
work of the younger poets who began writing in that decade. After the dictatorship many of the men of this generation, however, most importantly Lefteris Poulios and Vasilis Steriadis, stopped using woman as the figural terrain of resistance. Tied as this metaphor was to a political moment, it no longer seemed necessary. ${ }^{16}$ Many women poets, by contrast, did not view the regime's fall as definitive; according to them the question of authority as censorship or moral taboos, though perhaps more obvious under the authoritarian regime, did not disappear with the return to democracy. The issue was still relevant, for example, in relations between the sexes. Women poets such as Pavlina Pamboudi, Rea Galanaki, Jenny Mastoraki, and Maria Laina continued to challenge authority by reworking the effects of censorship as formal components of the text. These writers' poetics of distortion, condensation, displacement, reversal, and omission internalizes Cassandra's undecidability.

The poets' conflating of personal pronouns, which linguistically enacts the coimplication of victim and victor, is one of the more prevalent examples of this internalization. The title of

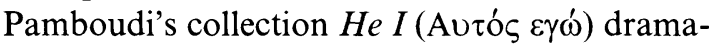
tizes the conflation. Similarly, in Galanaki's The Cake (То кर́ıк), feminine and masculine pronouns hopscotch across the text, turning male birds of prey into female ones and vice versa. Laina's poetic narrative Hers ( $\Delta$ เкó $\tau \eta \varsigma$ ) interjects an unexpected "him" after pages of feminine pronouns (40) and switches from "she" to "I" without warning (48), leaving the reader uncertain who is speaking. But nowhere is this undecidability more evident than in Mastoraki's Tales of the Deep.

Tales, like Mastoraki's two earlier volumes of poetry (Tolls [ $\Delta \mathrm{\imath ó} \delta \mathrm{\imath} \alpha]$ and Kin [To $\sigma o i]$ ), charts an appropriation of censorship as a writing strategy. The public limits and restrictions imposed by censorship are reworked in the form of the more personal struggles between lovers and are finally exposed as part of the writing process. This appropriation does not celebrate censorship but rather laboriously rehearses how it works. Instead of censoring the censor in the name of another ideology or - at the other extremeresorting to a completely uncensored stream-of- consciousness writing, Mastoraki's poetry experiments with an alternative method of resistance, one that introduces the effects of censorship into her own writing.

Throughout the twenty-seven macabre prose poems of Tales the confusion of subject and object, victim and victor, man and woman, reader and writer serves both as content and as linguistic register. As one line illustrates particularly well, it is impossible to determine who is

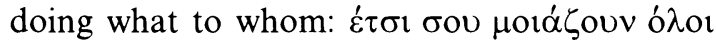

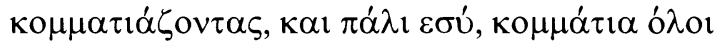
'so they resemble you, torn to shreds, and you them, again, in pieces' (17). Subject and object are thematically and syntactically implicated in each other. Tales begins with a hunter who has other hunters behind him, an image that undermines the opposition of victim and victor from

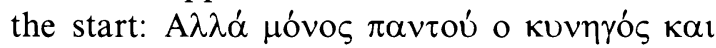
$\xi o \pi i \sigma \omega \tau$ เov $\delta 1 \omega \kappa \tau \varepsilon \varsigma$ 'But the hunter alone everywhere with pursuers on his trail' (11). The confusion is exacerbated by the unconventional placement of the adverb $\pi \alpha v \tau o u$ 'everywhere' between the adjective $\mu$ óvo $\varsigma$ 'alone' and the noun

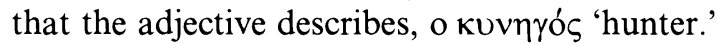
How can there be anyone behind someone who is everywhere?

This confusion is also true of sex roles. In the second poem men are feminized: Eкєi $\theta \alpha \pi \varepsilon \rho 1-$

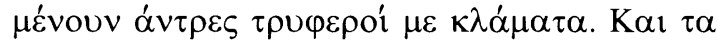

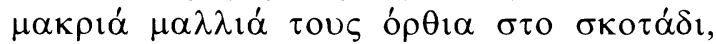
ó $\pi \omega \varsigma \tau \omega \nu \pi v \imath \gamma \mu \varepsilon \dot{\varepsilon} \omega \nu$ 'That is where tender men will wait in tears, their long hair floating in the dark. The hair of men who've drowned' (15). And this kind of gender scrambling is continually enacted in the syntax of the poems. In "The Unfortunate Brides" ("Oı како $\alpha \alpha \nu \tau \rho \varepsilon \mu \varepsilon \dot{\varepsilon \varepsilon \varsigma ”) ~}$ the women of the title seem to turn into the groom who threatened them. A series of similes equates their departure with glittering gold, first that of a sacrificial cock in Hades, then that of a golden jaw, and finally that of a rider on a horse, who recalls the groom (who took off), the molten gold perhaps referring to a stolen dowry:

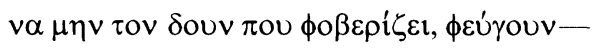

ó $\pi \omega \varsigma \alpha \sigma \tau \rho \alpha \dot{\phi} \phi \varepsilon \imath$ o $\pi \varepsilon \tau \varepsilon \imath$ v́s $\sigma \tau o v$ 'A $\delta \eta, \kappa \imath$ ó $\pi \omega \varsigma$

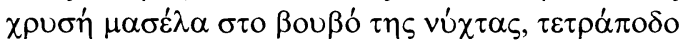




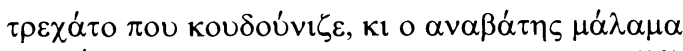

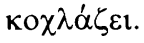

so they won't see him threaten, they leave-

the way a rooster lights up Hades, or a gilded jaw the speechless night, a beast jangling on the run, and the rider bubbles up gold.

In the last poem, "What That Epistle Said" ("Tl $\dot{\varepsilon} \lambda \varepsilon \gamma \varepsilon \varepsilon \kappa \varepsilon i v \eta \eta \varepsilon \pi \imath \sigma \tau 0 \lambda \eta \eta$ "), the victor not only turns into the victim and changes gender but also inverts the relation of writer and reader. The producer of the text, "I," which is qualified by groups of victimized women throughout the book - beautiful ladies of the underworld (16), abducted women (35) - turns into the victor, "he":

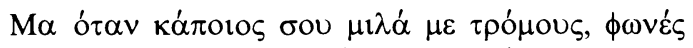

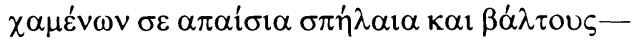

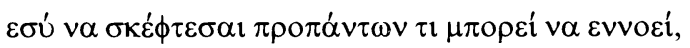

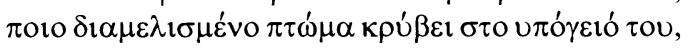

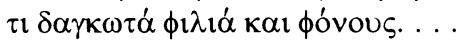

But when someone talks to you with terror, with voices of those lost in ghastly caves and marshes-

above all you must consider what he might mean, what dismembered corpse he is hiding in his cellar, what biting kisses, murders. ... (emphasis mine)

This victor, then, through the shifting of pronouns and scrambling of syntax in the middle section of the poem, is smothered so that the poem can conclude by asking the readers to feel sympathy for him:

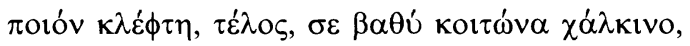

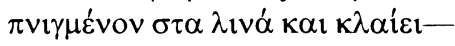

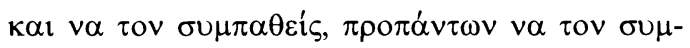

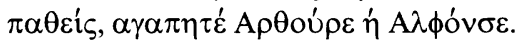

what thief, finally, in a deep, brass bedchamber, smothered in linen, and cries-

and you must feel for him, above all feel for him, my dear Arthur or Alphonse.

Through an odd kind of suicide the plural storyteller becomes singular and lies on his deathbed, and the reader, who up until this point is referred to in the singular "you," is made the plural recipient of the letter, "Arthur or Alphonse," and is handed responsibility for continuing the story. The plea to Arthur or Alphonse is an invitation to the readers to go back to the beginning, to the alpha, and write the epistle themselves.

These poems start with Kassandra's doll already in pieces. That no one is ever completely in control-neither the victor nor the victim, the man nor the woman, the writer nor the readeraffects language's ability to organize itself around fixed objects and subjects. Whereas in Karapanou's Kassandra and the Wolf censorship is challenged, for the most part, at the level of plot, in Mastoraki's Tales language itself enacts the equivalent of Karapanou's shifting sympathies, cross-dressing, and stuttering. The victor and the victim in Tales perform in the guise of floating pronouns, contradictory statements, dashes, blank spaces, double entendres, and quotation marks.

\section{Mastoraki's Use of Quotation and Irigaray's Subversive Mimesis}

The undermining of the authority of quotation marks provides a particularly succinct example of how power relations are explored formally in Tales. Mastoraki's juxtaposition of phrases within and without quotation marks raises the question of who has the right to speak for whom. Like elliptical syntax and other modes of obscuring meaning in recent Greek women's poetry, this technique derives its specific subversive potential from its deployment within the political and cultural context of Greece over the two decades since the dictatorship. As a formal reworking of the complication of victim and victor, censored and censor that woman had come to figure, this feature is further testimony that censorship was a problem not only under the authoritarian regime. To draw out the feminist implications of the challenge to authority in Tales, Mastoraki's use of quotation can be read in the light of Luce Irigaray's strategy of subversive mimesis. At the same time this feminist reading needs to be combined with Mastoraki's own view of her use of quotation as homage to the Greek literary tradition. 
Words in quotation marks, much like proper names, have a certain clout that other language cannot claim; quoting is one of the main textual practices by which writing is authorized. ${ }^{17}$ Though Tales borrows from canonical sources such as folk songs, the Bible, the works of nineteenth-century national poets, the adventure stories of Jules Verne, the short stories of Yeorgios Vizyenos - a prominent writer of the generation of the 1880 s - and Byzantine chronicles

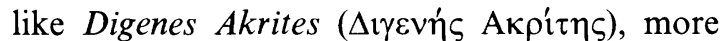
often than not the effect of these references is to undo the authority of the tradition. The volume's focus is on the heterogeneity of these intertexts rather than on their authenticity. The epigraph of Tales, from the short story "Who Was My

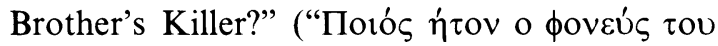
$\alpha \delta \varepsilon \lambda \phi o v '$ Hov"), by Vizyenos, is the most suspicious, since the citation is the only one linked by a note to its author. The epigraph states:

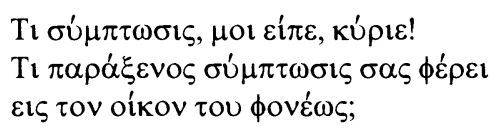

What coincidence, sir, he said to me, what strange coincidence brings you to the house of the murderer?

This passage signals to readers who know the Vizyenos tale that they should be cautious in interpreting the epigraph as a gesture of deference; things are never as they appear to be. Just as the speaker refers to an inversion (the moment in which the narrator of the tale, in pursuit of his brother's murderer, finds that what he thought was the victim's house is the killer's), so may the function of the quotation be inverted: instead of lending an air of certainty, the borrowed words may repeat the uncertainty and confusion that is present everywhere in Tales. In the new context, for example, Vizyenos's "you" no longer designates only a specific character but encompasses anyone reading Mastoraki's poems. Again and again Tales undoes the authority of quotations by recontextualizing them. ${ }^{18}$

One poem in particular, "The Divers" ("Or

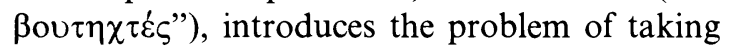
something out of its context and making it exemplary. The poem, which recounts the way writers gather material for stories, begins with a list. The importance of the quotation marks in the first item is deflated by the pluralizing of the borrowed statement and by the juxtaposition of all sorts of other phrases: ${ }^{19}$

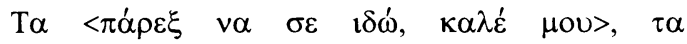

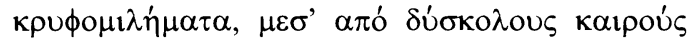

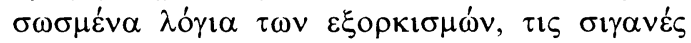
$\pi \alpha \tau \eta \mu \alpha \sigma ı \varepsilon_{\varsigma}, \tau \alpha \pi$ oı́n $\mu \alpha \tau \alpha, \alpha \pi$ ó $\pi \varepsilon \imath \rho \varepsilon \varsigma \alpha \gamma \vee$ oov-

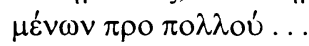

Those "nothing, save to see you, my love"s, hushed conversations, the words to exorcisms salvaged from difficult times, the quiet footsteps, poems, attempts of those missing for ages ...

The poem seems to conclude with an even more striking undermining of the authority of quotations:

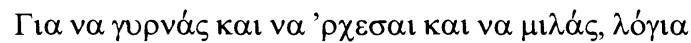

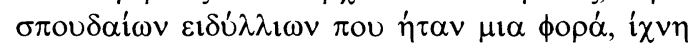
$\lambda \alpha \mu \pi \rho \dot{v} v \kappa \alpha \rho \alpha \tau o \mu \eta \dot{\eta} \sigma \varepsilon \omega v, \tau \alpha<\sigma \varepsilon \phi i \lambda \omega \dot{\omega}>, \alpha \chi \pi$ ó $\sigma o$

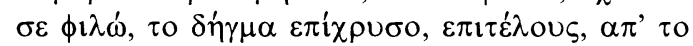

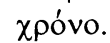

So that you will return and come over and talk, words from great romances that happened long ago, traces of glorious beheadings, those "I kiss you"s, oh yes I kiss you, and the bite, at last, gilded by time.

This time the citation is thrice stripped of authority, first by being modified by a plural adjective, "those," then by being repeated without quotation marks, and finally by the suggestion that what the quotation concerns is not a kiss at all but "a bite." Like the conflation of victor and victim or man and woman, the dissolution of a quotation into language that is unmarked relies on a strategy of subversion. Beginning and ending with quotations that are denied their authority, this poem urges the reader to admit the way texts participate in the power dynamics they address. The more attention that is paid to how writing is controlled, the more adept writers and readers become at disturbing authority - that of the censor as well as their own. 
Like Tales, Speculum of the Other Woman, through Irigaray's strategy of subversive mimesis, ${ }^{20}$ formally overturns the authority of quotation by injecting uncertainty where certainty is assumed. The first section, entitled "How Can They Immediately Be So Sure?," cites Freud's lecture on femininity but undoes the authority of the document by repeatedly interrupting and qualifying his meaning:

"When you meet a human being," he says, they say,
first of all, "the first distinction you make is 'male
or female?' and you are accustomed to making the
distinction with unhesitating certainty." How? This
remains implicit and seems to require no remark
among yourselves. Silence, then, on the subject of
that extreme assurance which keeps you from being
mistaken at first sight about the sex of the person
you run across. The important point, it seems, is for
you to be firmly convinced, without possible hesi-
tation, that you cannot be in error, that there is no
ambiguity possible...

Like the words "I kiss you," which euphemistically cover up a bite in Mastoraki's poem, Freud's extreme assurance sounds defensive in the context of Irigaray's text. Both authoritative statements are not what they appear to be. But Speculum's undermining of authority, in contrast to Tale's, has an explicitly feminist goal. Irigaray challenges Freud's "phallogocentrism" in the name of "the other woman," who does not constitute herself as lacking a phallus. Irigaray argues that for too long men have censored women by speaking among themselves about femininity; it is time for women to intervene. Irigaray thus genders censorship and advocates a "feminine" way of writing in response.

Tales also addresses inequality between the sexes, but in the light of Irigaray's positive inscription of the other woman, Mastoraki's project appears to be negative. Rather than a gesture toward new forms of feminine sexuality, Mastoraki's challenge to authority, like Karapanou's, seems an attempt to feminize masculinity. Tales teems with sensitive men and ends with a male thief crying. This insistence on men who do not conform to stereotype is close to the critique that Kaja Silverman reaches in discussing Iri- garay. Silverman concludes that "what passes for 'femininity' is actually an inevitable part of all subjectivity. ... [W] hat is needed here is . . a 'feminization' of the male subject" (149). Mastoraki's formal reworking of woman's undecidability feminizes writing in the name of turning men into women. Instead of constructing a space for an alternative feminine imaginary, her use of quotation expands the realm of the (predominantly male) Greek literary imagination to include female experiences.

Mastoraki's own discussion of her use of quotation in Tales helps clarify this difference, even if her observations are not conclusive. She too views quotation as a way to use the literary tradition to her own ends, but instead of seeking to undermine the authority of the tradition, she concentrates on how citation enables her as a poet. For her, quotation is a necessary condition of writing in Greek, since the unusually layered history of the language requires that the Greek speaker always use others' words. She writes:

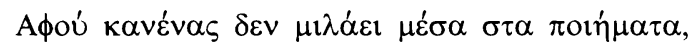

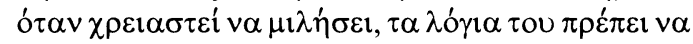

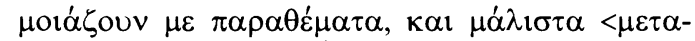

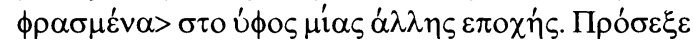

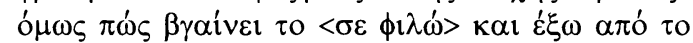

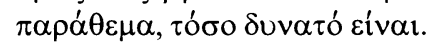

(Letter)

Since no one speaks in [these] poems, when someone has to speak, the spoken words must resemble quotations, moreover quotations "translated" from another time. Watch, though, how the "I kiss you" breaks out of the quotation marks, it's so strong.

For Mastoraki, the repetition of the line "I kiss you" enacts an escape, but instead of dismantling the master's house with his own tools, as I suggest, the line acknowledges quotation as a central means of overcoming silence. While I relate the effects of censorship in Tales specifically to the dictatorship and to the rise of the women's movement in Greece, Mastoraki views them more generally as a condition of writing. In fact, she denies that the political struggle of victor and victim, censor and censored figuring prominently in her early poetry written under the dictatorship is connected to the more personal 
struggle of lovers trying to communicate in

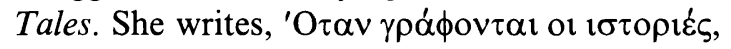

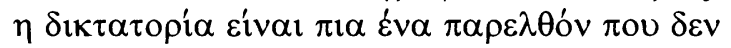

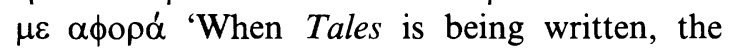
dictatorship is already a past that no longer concerns me' (Letter).

Mastoraki's comments imply that her poem "The Divers" can be read as also collusive with the structures of power I suggest it undermines. The reception of Tales by the Greek critical establishment supports this impression. Whereas Irigaray was expelled from the Ecole Freudienne for Speculum, Mastoraki was lauded by one of the most influential male critics in Greece (Ma-

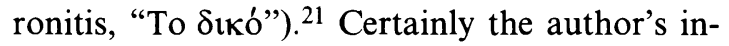
tentions and the response of critics cannot be ignored, but, again, taking them at face value is less fruitful than reading them in relation to other historical and theoretical claims, such as those of censorship and of gender.

An additional way to contextualize my discussion of quotation is to acknowledge the different academic environments in which Irigaray's and Mastoraki's texts circulate. It could be argued that Speculum and much of poststructuralist French feminist theory-calling, as they do, for interdisciplinary thinking - are critical responses to the near autonomy of disciplines such as philosophy, political science, and literature in France. Because disciplines in Greece have always been more interdependent than those in France, Mastoraki's linguistically heterogeneous text does not threaten the Greek critical establishment. Only recently has literature in Greece become an autonomous institution; literary histories have usually included a wide range of writings, from folk songs to religious tracts to political manifestos (Lambropoulos 23-43; Jusdanis 108-13). The different receptions of Irigaray's and Mastoraki's texts could be further explained if subversive mimesis was placed in the light of the contrasting attitudes toward the new held by French writers, who tend to esteem innovation, and by Greek writers, who are inclined to mistrust it. Whereas Irigaray participates in a culturally acceptable practice when, as an avant-garde writer, she undermines her predecessors, Mastoraki works in a milieu where breaking with tradition is less likely to be valued.
Irigaray certainly helps to reveal the feminist implications of Mastoraki's challenge to authority, but Mastoraki's reading of "The Divers" can be used to uncover Irigaray's investment in the avant-garde as a tradition. The critical approach I advocate, therefore, requires that the ground of investigation shift continuously, so that a text can be viewed both cross-culturally, in relation to other texts, and intraculturally, according to the modes available for acknowledging social change in the author's culture. ${ }^{22}$

At the end of her last lecture on Cassandra, Wolf makes a parallel between this seeress and the soothsaying Pythia: "At first men had identified with women, mimed the birth process, castrated themselves so they could become priests. . . . At Delphi later . . . the woman becomes a tool in the hand of the men. ... The woman, once the executant, has either been excluded or turned into an object." Wolf then addresses her contemporaries Ingeborg Bachmann and Heiner Müller and suggests that once again the time has come for women to set the agenda. She challenges Müller's comment "It is good to be a woman and no victor . . ." by asking, "Do people expect, do we expect, how difficult and in fact dangerous it can be when life is restored to an 'object'? When the idol begins to feel again? When 'it' finds speech again? When it has to say 'I,' as a woman?” (292-93). Wolf's question is echoed in Karapanou's challenge to the fixity of the male subject and again in Mastoraki's display of this disintegration in her syntax and use of quotation. After the dictatorship, to say "I" as a woman became a desirably unsettling way of sustaining an analysis of power relations, since this I was, as Karapanou's Kassandra insists, never either a gentleman or a lady but both and was, as Mastoraki's confusing syntax demonstrates, not definitively subject or object. By relating the censorship of the colonels to that of patriarchy and then internalizing the enemy, Karapanou and Mastoraki, among others, are able to offer women, as well as men, a more complex notion of subjectivity and writing than was previously available. ${ }^{23}$ 


\section{Notes}

${ }^{1}$ Moreover, many of the most well-established Greek male writers started writing in women's voices (e.g., Thanasis Valtinos, in Dark Blue Almost Black [M $\pi \lambda \varepsilon \beta \alpha \theta \dot{\text { u }} \sigma \chi \varepsilon \delta \delta$ v

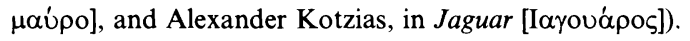

Anghelaki-Rooke is often grouped with these poets, although her first book came out in 1963. After three collections of poetry, Galanaki turned to prose, and she is now better known as a novelist.

Undocumented translations are mine. I do not focus on the problem of translation in this article, although the notion of reading between worlds developed here is informed by theories of translation that insist on the incommensurability of different linguistic experiences (Benjamin; Derrida; Spivak, "Politics"). For an introduction to the specific issues of translating Greek literature, see Journal.

${ }^{2}$ For discussions of women's role in the oral tradition, with focus on the lament, see Alexiou; Serematakis; and HolstWarhaft. Holst-Warhaft connects women's writing to this tradition.

${ }^{3}$ For a consideration of Roidis and of the Ladies' Journal

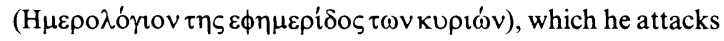
here, see Varika 16, 193-94.

${ }^{4}$ Drawing on the work of the Chilean feminist Juliet Kirkwood, Jean Franco makes a similar point about women in Latin America. She describes how "authoritarian regimes often forced women to make connections between state repression and oppression at home" (68).

${ }^{5}$ During the dictatorship leftists and rightists, who had been mortal enemies twenty years earlier, suddenly found themselves working together in opposition to the colonels. When the socialist government instituted equal status for veterans of both sides in 1981 and encouraged open debate about the civil war, there was a general consensus that the end of an extremely painful era was in sight. The Government of National Unity, of November 1989, whose cabinet contained representatives of the three main parties (left, right, and center), among others, would have been inconceivable without two decades of less official collaboration and tolerance.

${ }^{6}$ Between 1981 and 1983 divorce by mutual consent was legalized, the dowry was abolished, and an equal-pay policy was established. See Stamiris on the contemporary women's movement in Greece.

${ }^{7}$ The theoretical analogue to the fading of memories of the civil war and to the rise of the women's movement was the acceptance of psychoanalysis by the Left. In a discussion in 1984 about the influence of Marxist thought on literature in Greece since 1920, the poet Manolis Anagnostakis pointed out that already in the 1940s there was a need for the Left to integrate the lessons of psychoanalysis but that it was not until the 1970s that this need was widely acknowledged (Kendro 41).

In The Interpretation of Dreams Freud uses the term censorship to address the mechanisms of repression-distortion, condensation, displacement, reversal, omission. His aim is not to get rid of repression but, as Anna Freud elaborates, "to reconstruct the measures adopted by the censor" (16).

${ }^{8} \mathrm{On}$ the ambivalent relation of Greece to Europe see Herzfeld, Anthropology and Ours Once More; Jusdanis.

${ }^{9}$ This conservative condemnation of long hair has a wellestablished precedent in the turn-of-the-century critique of $\mu \alpha \lambda \lambda$ i $\alpha \rho \sigma \mu \mu$ ' $\varsigma$ 'hairism' by the $\kappa \alpha \theta \alpha \rho \varepsilon v o v \sigma i \alpha v o r$ (the advocates of $\kappa \alpha \theta \alpha \rho \varepsilon v$ ov $\sigma \alpha$, or purist Greek) in the language controversy (Mackridge 30-31). The connection appears more than casual when one considers the colonels' attempt to reinstate $\kappa \alpha \theta \alpha \rho \varepsilon \dot{v} о u \sigma \alpha$.

${ }^{10}$ That this text was printed in the former German Democratic Republic with certain passages censored attests to the contemporary impact of Wolf's critique.

${ }^{11}$ The classical source suggested by the name Kassandra is also present in Karapanou's novel.

${ }^{12}$ Kassandra and the Wolf could also lead to an alternative reading of Wolf's volume, one that challenges her search for origins. Talking in an interview about the danger of letting myth efface history, Wolf mentions how an event that takes on mythic proportions, such as the Trojan War, "tends to push the organization of the material in the direction of a certain closure," but, she adds, "the structure of the lectures ... helps to force open this closed form" (Fourth Dimension 117). Karapanou's contemporary Kassandra might be used to deconstruct this distinction between the novel and the lectures by exposing the transhistoricizing slips in the lectures themselves. For example, while referring in one lecture to the modern Greek partisan in a novel by Thanasis Valtinos, Wolf conflates the character with Orpheus, assuming exactly the kind of romantic continuity from ancient to modern times that many contemporary Greek writers question (184-85). Wolf's demythologization of Cassandra is at times premised on the very myth of continuity that it denounces.

${ }^{13}$ Karapanou's novel also offers a frame for examining Wolf's undermining of the authoritarian demands of socialist realist dogma in East Germany. The recent debate over Wolf's relation to the regime illustrates how precarious resistance is (Huyssen; Hafner).

${ }^{14}$ For a brief cultural survey of contemporary society in eastern Germany see John Borneman's After the Wall, in particular his description of how education in the former East Germany prepared students to read between the lines and to internalize contradictions (220-25). I am grateful to Charles Stewart for calling my attention to this book.

${ }^{15}$ In other words, instead of calling for multiple identities, she insists that identity itself is split. Diana Fuss theorizes a similar position when she critiques certain social constructivists for not taking into account the Lacanian notion of the split subject. She writes, "What worries me . . . is that difference is relocated from the space within identity to the space between identities. Difference is seen as a product of the friction between easily identifiable and unitary components (sexual, racial, economic, national . . .) competing for dominance within the subject" (103).

${ }^{16}$ For an extended analysis of this shift that focuses on Poulios's and Steriadis's poetry, see Van Dyck, Writing, ch. 2. 
${ }^{17}$ Deconstructive readings stress the difficulty of undermining the authority of quotations and of proper names. Lacan's, Derrida's, and Johnson's readings of Poe's "The Purloined Letter" provide an excellent showcase. Johnson sums up the problem when she admits that through the act of quotation each text (Poe's, Lacan's, Derrida's, hers) inevitably bears the stamp of the quoted author, which determines the newer text's meaning whether or not the quoting author acquiesces. Writing always seems to participate in the authority it seeks to subvert. "[T]he rectification of a previous injustice somehow irresistibly dictates the filling in of a blank which then becomes the new injustice..." (Johnson 218).

${ }^{18}$ Similarly, Mastoraki undermines the authority of the proper name. The alternative names at the end of TalesArthur and Alphonse-deprive naming of its proper function since a name is only authoritative if its referential status is determinate.

${ }^{19}$ To discuss quotation in this poem, I have had to resort to a more literal rendering in English, thus partially losing the anapestic rhythm I retain in my other translations of poems from Tales.

${ }^{20}$ Moi (127-49) and Gallop provide insightful analyses of Speculum. Moi usefully introduces the term "subversive mimesis" to refer to Irigaray's practice of citing an authority (Freud, Plato) and then undermining his logic (130).

${ }^{21}$ In keeping with the unavoidable desire to stabilize meaning - the logic of the purloined letter outlined in note 17Mastoraki's next collection after Tales, With a Crown of

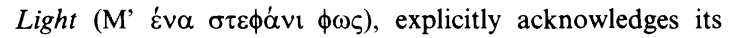
indebtedness to the Greek literary tradition, in particular to the work of the national poet Solomos. Whereas the use of quotation in Tales can be read as both subversive and collusive, the citational technique in this volume, in which Mastoraki clearly attributes quotations to their authors, is no longer undecidable. It is no coincidence that this collection met with even greater critical acclaim than did Tales.

${ }^{22}$ Such an approach also involves making explicit the ways in which my own cultural context determines the kind of questions I ask. In Irigaray's dialogue with various French, Italian, and American feminists $(\mathrm{Je})$, it is the questions posed by the American feminists Alice Jardine and Anne Menke that mirror the issues of the canon and interdisciplinary studies that I turn to in explaining Mastoraki's and Irigaray's different receptions. These concerns are distinctly those of North American feminists, not of French or Italian ones.

${ }^{23}$ I would like to thank Daniela Daniele, Vassilis Lambropoulos, Maria Leontsini, Nelson Moe, Yopie Prins, Dorothea von Mücke, and Susan Winnett for their comments on earlier drafts of this article.

\section{Works Cited}

Alexiou, Margaret. The Ritual Lament in Greek Tradition. Cambridge: Cambridge UP, 1974.

Anghelaki-Rooke, Katerina. Beings and Things on Their Own. Trans. Jackie Willcox, with Anghelaki-Rooke. Brockport: BOA, 1986.
- The Body Is the Victory and the Defeat of Dreams. Trans. Philip Ramp. San Francisco: Wire, 1975.

Benjamin, Walter. "The Task of the Translator." Illuminations. Ed. and introd. Hannah Arendt. Trans. Harry Zohn. New York: Harcourt, 1968. 69-82.

Borneman, John. After the Wall. New York: Basic, 1991.

Carby, Hazel. "White Women Listen! Black Feminism and the Boundaries of Sisterhood." The Empire Strikes Back: Race and Racism in Seventies Britain. London: Hutchinson, 1982. 212-33.

Cavafy, C. P. Collected Poems. Trans. Edmund Keeley and Philip Sherrard. Princeton: Princeton UP, 1975.

-. Moı' $\mu \alpha \tau \alpha$ A' $^{\prime}$ Poems 1]. Athens: Ikaros, 1963.

Clogg, Richard. "The Ideology of the 'Revolution of 21 April 1967.'" Greece under Military Rule. Ed. Clogg and George Yannopoulos. New York: Basic, 1972. 36-58.

Derrida, Jacques. "Des Tours de Babel." Difference in Translation. Ed. and trans. Joseph F. Graham. Ithaca: Cornell UP, 1985. 165-248.

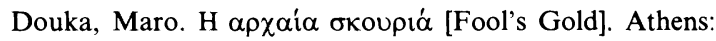
Kedros, 1979.

- Fool's Gold. Trans. Roderick Beaton. Athens: Kedros, 1991.

Fakinou, Eugenia. To \&́ $\beta \delta \circ \rho_{0} \rho o u ́ \chi 0$ [The Seventh Garment]. Athens: Kedros, 1983.

. The Seventh Garment. Trans. Ed Emery. London: Serpent's Tail, 1992.

Franco, Jean. "Going Public: Reinhabiting the Private." On Edge: The Crisis of Contemporary Latin American Culture. Ed. George Yúdice, Jean Franco, and Juan Flores. Minneapolis: U of Minnesota P, 1992. 65-83.

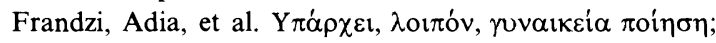
[So, Is There Women's Poetry?]. Athens: Etaireia Spoudon, 1990.

Freud, Anna. The Ego and the Mechanisms of Defence. Trans. Cecil Baines. Ed. John D. Sutherland. London: Hogarth; Inst. of Psychoanalysis, 1986.

Freud, Sigmund. The Interpretation of Dreams. Trans. James Strachey. Ed. Angela Richards. Harmondsworth, Eng.: Penguin, 1976.

. On Metapsychology: The Theory of Psychoanalysis. Trans. James Strachey. Ed. Angela Richards. Harmondsworth, Eng.: Penguin, 1984.

Fuss, Diana. Essentially Speaking: Feminism, Nature and Difference. London: Routledge, 1989.

Galanaki, Rea. To к'́ıк [The Cake]. Athens: Kedros, 1980.

Gallop, Jane. "The Father's Seduction." The (M)Other Tongue: Essays in Feminist Psychoanalytic Interpretation. Ed. Shirley Nelson Garner, Claire Kahane, and Madelon Sprengnether. Ithaca: Cornell UP, 1985. 3350.

Hafner, Katie. "A Nation of Readers Dumps Its Writers." New York Times Magazine 10 Jan. 1993: 22+.

Hauser, Kornelia. "Sexuality and Power." Female Sexualization. Ed. Frigga Haug. London: Verso, 1987. 185-230.

Herzfeld, Michael. Anthropology through the Looking-Glass. Critical Ethnography in the Margins of Europe. Cambridge: Cambridge UP, 1987. 
Ours Once More: Folklore, Ideology, and the Making of Modern Greece. Austin: U of Texas P, 1982.

Holst-Warhaft, Gail. Dangerous Voices: Women's Laments and Greek Literature. London: Routledge, 1992.

Hooks, Bell. Talking Back: Thinking Feminist, Thinking Black. Boston: South End, 1989.

Huyssen, Andreas. "After the Wall: The Failure of German Intellectuals." New German Critique 52 (1991): 109-43.

Irigaray, Luce. Je, tu, nous. Pour une culture de la différence. Paris: Grasset, 1990.

- Speculum of the Other Woman. Trans. Catherine Porter, with Carolyn Burke. Ithaca: Cornell UP, 1985. Trans. of Speculum de l'autre femme. 1974.

Johnson, Barbara. "The Frame of Reference: Poe, Lacan, Derrida." The Purloined Poe: Lacan, Derrida, and Psychoanalytic Reading. Ed. John P. Muller and William J. Richardson. Baltimore: Johns Hopkins UP, 1988. 213-51.

Journal of Modern Greek Studies 8.2 (1990): 169-343.

Jusdanis, Gregory. Belated Modernity and Aesthetic Culture: Inventing National Literature. Minneapolis: U of Minnesota $\mathrm{P}, 1991$.

Karapanou, Margarita. Kassandra and the Wolf. Trans. Nick Germanacos. New York: Harcourt, 1974.

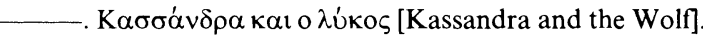
Athens: Ermis, 1976.

- O v $\pi v o \beta \alpha$ ' $\tau \varsigma$ [The Sleepwalker]. Athens: Ermis, 1985.

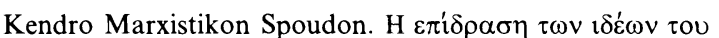

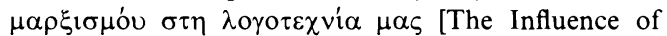
Marxist Ideas on Our Literature]. Athens: Kendavros: 1986.

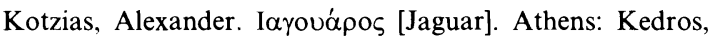
1987.

_. Jaguar. Trans. H. E. Criton, Athens: Kedros, 1991.

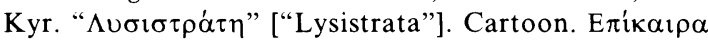
1 Mar. 1974: 15

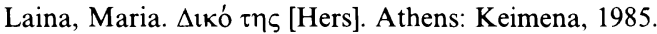

Lambropoulos, Vassilis. Literature as National Institution: Studies in the Politics of Modern Greek Criticism. Princeton: Princeton UP, 1988.

Mackridge, Peter. "Katharevousa (c. 1800-1974): An Obituary for an Official Language." Background to Contemporary Greece. Ed. Marion Sarafis and Martin Eve. Vol. 1. London: Barnes, 1990. 25-51.

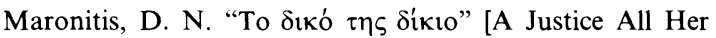

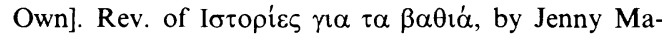
storaki, and $\Delta$ เкó $\tau\rceil \varsigma$, by Maria Laina. Bín $\mu 23$ May 1985: 16.

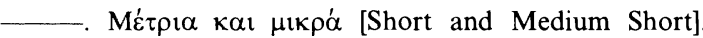
Athens: Kedros, 1987.

Mastoraki, Jenny. $\Delta$ ió $\delta$ เ $\alpha$ [Tolls]. Athens: Kedros, 1972. - I $\sigma \tau \rho \rho^{\prime} \varepsilon \varsigma \gamma / \alpha \tau \alpha \beta \alpha \theta \theta^{\prime} \alpha$ [Tales of the Deep]. Athens: Kedros, 1983.

_. Letter to the author. 17 Nov. 1992.
M' $\varepsilon v \alpha \sigma \tau \varepsilon \phi \alpha^{\prime} v i$ $\phi \omega \varsigma$ [With a Crown of Light]. Athens: Kedros, 1989.

. To бoï [Kin]. Athens: Kedros, 1978.

Moi, Toril. Sexual/Textual Politics: Feminist Literary Theory. London: Methuen, 1985.

Pamboudi, Pavlina. Autós ع $\gamma \omega \dot{\omega}$ [He I]. Thessaloniki: Mikri Egnatia, 1977.

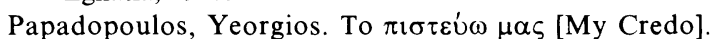
Vol. 2. Athens: Press Office, 1968.

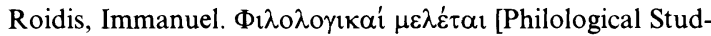
ies]. Athens: Fexi, 1913.

Serematakis, Nadia. The Last Word: Women, Death, and Divination in Inner Mani. Chicago: $U$ of Chicago P, 1991.

Silverman, Kaja. The Acoustic Mirror: The Female Voice in Psychoanalysis and Cinema. Bloomington: Indiana UP, 1988.

Spivak, Gayatri Chakravorty. "French Feminism in an International Frame." In Other Worlds: Essays in Cultural Politics. London: Methuen, 1987. 206-24.

_ . "French Feminism Revisited: Ethics and Politics." Feminists Theorize the Political. Ed. Judith Butler and Joan Scott. London: Routledge, 1992. 54-85.

. "The Politics of Translation." Destabilizing Theory: Contemporary Feminist Debates. Ed. Michèle Barrett and Anne Philips. Stanford: Stanford UP, 1992. 177200.

Stamiris, Eleni. "The Women's Movement in Greece." New Left Review 158 (1986): 98-112.

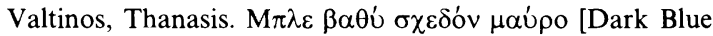
Almost Black]. Athens: Stigmi, 1986.

Van Dyck, Karen. Cassandra and the Censors: Greek Poetry since 1967. Ithaca: Cornell UP, forthcoming.

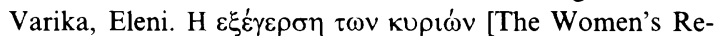
volt]. Athens: Idrima Erevnas kai Paideias, 1987.

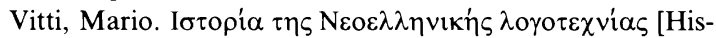
tory of Modern Greek Literature]. Trans. Myrsini Zorba. Athens: Odysseas, 1987

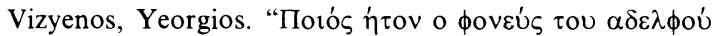
$\mu o v$ " ["Who Was My Brother's Killer?']. To $\alpha \mu \alpha \rho \tau \eta \mu \alpha$

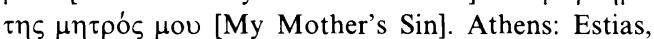
1973. 41-99.

- "Who Was My Brother's Killer?" "My Mother's Sin" and Other Stories. Trans. William F. Wyatt, Jr. Hanover: UP of New England, 1988. 53-94.

Wolf, Christa. Cassandra: A Novel and Four Essays. Trans. Jan van Heurck. London: Virago, 1984.

- The Fourth Dimension: Interviews with Christa Wolf. Trans. Hilary Pilkington. Introd. Karin McPherson. London: Verso, 1988.

Zei, Alki. Achilles' Fiancée. Trans. Gail Holst-Warhaft. Athens: Kedros, 1991.

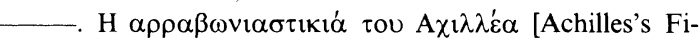
ancée]. Athens: Kedros, 1987. 